\title{
STRATEGI MENINGKATKAN VOLUME PENJUALAN KRIPIK TEMPE DI MASA PANDEMI PADA HOME INDUSTRY SUMBER AGUNG, PETORAN, JEBRES, SURAKARTA
}

\author{
Marjam Desma Rahadhini ${ }^{{ }^{*}}$ \\ Fakultas Ekonomi, Universitas Slamet Riyadi Surakarta \\ email: rahadhininew@gmail.com \\ Lamidi $^{2}$ \\ Fakultas Ekonomi, Universitas Slamet Riyadi Surakarta \\ email: lamidi71@gmail.com
}

\begin{abstract}
This community activity takes the object of the Sumber Agung home industry in Petoran, Jebres, Surakarta. The purpose of the activity is to provide training and counseling to Sumber Agung home industry managers in order to be able to adapt to changes in information technology, in an effort to manage and develop their business, and to help provide solutions to overcome problems faced, especially in the aspect of product marketing, among others: 1) during the covid 19 pandemic the sales of tempe chips experienced a very significant decline, around $50 \%$, 2) the tempe slicing process is only done manually, even though under normal conditions it can consume $70 \mathrm{~kg}$ of soybean raw material/day, as a result it is inefficient in production, 3) the owner does not understand the importance of branding and packing. The method of implementing this activity is by providing assistance in the form of training and counseling at the Sumber Agung home industry. Technically, by holding training on the use of social media (whatsapp, facebook and instagram) and counseling on the importance of understanding branding and packing. The results of this mentoring activity were Facebook which was used by "Kripik Sumber Agung" and Instagram which was used by "Sumberagungsolo". The output of this activity, the articles published in the National Accredited Journal.
\end{abstract}

Keywords: tempe chips, mentoring, social media

\section{ABSTRAK}

Kegiatan pengabdian kepada masyarakat ini, mengambil obyek home industry Sumber Agung di Petoran, Jebres, Surakarta. Tujuan dilakukan pengabdian untuk memberikan pelatihan dan penyuluhan kepada pengelola home industry Sumber Agung agar mampu beradaptasi terhadap perubahan tehnologi informasi, dalam upaya mengelola dan mengembangkan usahanya, serta membantu memberikan solusi untuk mengatasi permasalahan yang dihadapi, khususnya pada aspek pemasaran produk. Beberapa permasalahan yang dihadapi, antara lain: 1) pada masa pandemi covid 19 penjualan kripik tempe mengalami penurunan yang sangat signifikan, sekitar 50\%. 2) proses pengirisan tempe hanya dilakukan secara manual, padahal dalam kondisi normal dapat menghabiskan bahan baku kedelai $70 \mathrm{~kg} / \mathrm{hari}$, akibatnya tidak efisien dalam produksi, 3) pemilik belum memahami makna pentingnya branding dan packing. Metode pelaksanaan pengabdian ini dengan melakukan pendampingan dalam bentuk pelatihan dan penyuluhan pada home industry Sumber Agung. Secara tehnis dengan mengadakan pelatihan penggunaan media sosial (whatsapp, facebook dan instagram) dan penyuluhan tentang pentingnya memahami branding dan packing. Hasil dari kegiatan pendampingan ini, facebook yang digunakan "Kripik Sumber Agung" dan instagram yang digunakan "Sumberagungsolo". 
Luaran dari kegiatan pengabdian ini, artikel pengabdian yang dimuat di Jurnal Pengabdian Terakreditasi Nasional.

\section{Kata kunci: kripik tempe, pendampingan, sosial media}

\section{PENDAHULUAN}

Terjadinya pandemi covid 19 , awal mula hanya terjadi di negara China dan pada akhirnya menyebar pada seluruh dunia termasuk negara Indonesia. Terjadinya pandemi covid 19 menyebabkan terjadinya penurunan angka pertumbuhan ekonomi China antara $2 \%$ $6 \%$ dibandingkan sebelum terjadinya pandemi (Khan dan Faisal, 2020). Sedangkan covid 19 masuk ke negara Indonesia, awal bulan Maret 2020 dan sampai sekarang penyebaran virus covid di Indonesia belum bisa dikendalikan, bahkan sampai Mei 2021. Pada bulan Januari 2021 grafik pasien positif yang terkena covid terus naik. Menurut data pada 19 Januari 2021, pasien positif covid 19 menembus jumlah 10.365 orang/hari (news.detik.com).

Terjadinya pandemi covid 19 di Indonesia berdampak pada semua sektor, antara lain: sektor perdagangan, pariwisata, sektor usaha dan sektor perbankan. Munculnya pandemi covid 19 berpengaruh terhadap eksistensi usaha/bisnis dalam menjalankan usahanya (Taufik dan Ayuningtyas, 2020) yang pada akhirnya berimbas pada kondisi makro ekonomi negara Indonesia. Kenyataan ini memaksa pemerintah melakukan berbagai kebijakan ekonomi melalui stimulus fiskal ataupun moneter, stimulus fiskal salah satunya diberikan pada sektor UMKM, dimana pelaku usaha pada sektor ini mendapatkan bantuan stimulus sebesar Rp 600.000/bulan (jangka waktu 4 bulan). Hal ini dilakukan dalam rangka mengurangi beban ekonomi pelaku usaha terdampak pandemi.

Salah satu pelaku usaha yang terdampak pandemi covid 19 adalah home industry kripik tempe dan bayam (Sumber Agung) yang beralamat di Petoran RT 3, RW 7, Jebres, Surakarta. Usaha kripik ini dikelola oleh Bapak Sunardi dan Ibu Supriyanti, meneruskan usaha orang tua yang telah dirintis sejak awal tahun 1990 sampai sekarang (sudah berjalan selama 30 tahun). Dampak yang dirasakan karena adanya covid 19 yaitu daya beli masyarakat menurun, harga bahan baku kedelai meningkat, yang pada akhirnya berimbas pada biaya produksi meningkat dan volume penjualan produknya menurun. Penurunan daya beli masyarakat terjadi karena masyarakat mengurangi frekuensi keluar rumah, sesuai intruksi dari pemerintah dalam rangka memutus mata rantai penyebaran virus covid 19 salah satunya menjaga jarak (physical distancing). Dampak yang kedua, yaitu kenaikan harga kedelai dari sebelumnya antara Rp 6.500 - Rp $7.000 / \mathrm{kg}$, menjadi berkisar antara Rp 8.500 Rp 9.000. Kenyataan ini memaksa pelaku usaha memutar otak, bagaimana caranya supaya usaha yang telah dijalankan dapat tetap eksis pada masa pandemi ini. Sebelum pandemi, dapat menghabiskan bahan baku kedelai sekitar 60 $\mathrm{kg} / \mathrm{hari}$, sedangkan pada masa pandemi ini bahan baku kedelai hanya berkisar $40 \mathrm{~kg} / \mathrm{hari}$, hal ini berarti omset penjualan kripik tempe juga turun sekitar 50\%. Home Industry Sumber Agung lebih memfokuskan pada produk kripik tempe, sedangkan produk pelengkapnya adalah kripik bayam.

Profil dari Home Industry Sumber Agung dalam menjalankan usahanya masih menerapkan manajemen sederhana, sebagaimana dilakukan oleh sebagian besar pelaku usaha sektor Mikro (UMKM) di Indonesia. Penerapan manajemen sederhana yang dilakukan oleh home industry Sumber Agung, dapat dilihat pada beberapa kegiatan, yaitu:

a. Proses produksi kripik tempe

Mulai dari proses pengirisan tempe, pengirisan tempe dilakukan secara manual dengan pisau biasa, dibantu dengan alat hasil rekayasa sendiri untuk menaikkan/ menurunkan tempe yang siap diiris, dimana alat bantu tersebut digerakkan oleh kaki kiri dengan tujuan supaya tingkat ketebalan irisan tempe merata. Proses pengirisan tempe terlihat pada Gambar 1.

\footnotetext{
* Koresponden
} 


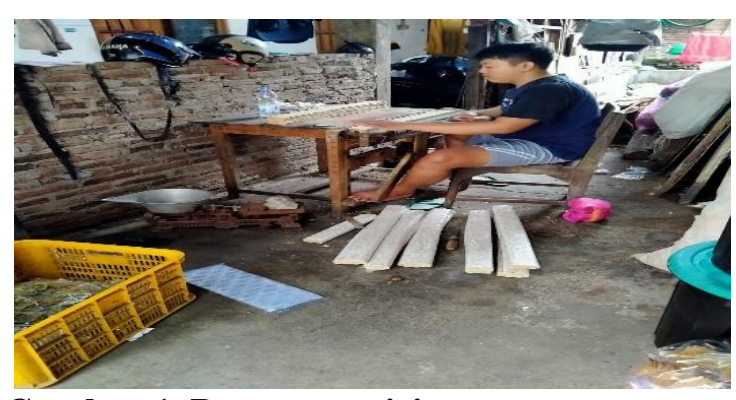

Gambar 1. Proses pengirisan tempe

b. Proses penggorengan tempe

Proses penggorengan juga masih sangat sederhana, dengan menggunakan tungku yang berbahan bakar dengan kayu bakar. Proses penggorengan ini dilakukan melalui 2 (dua) tahap yaitu:

1) Tahap 1, digoreng setengah matang pada tungku dan wajan yang pertama, selanjutnya hasil penggorengan yang pertama didiamkan sekitar 15-20 menit, baru masuk tahap 2.

2) Tahap 2, digoreng sampai matang pada tungku dan wajan yang kedua.

Adapun proses penggorengan kripik tempe terlihat pada Gambar 2.

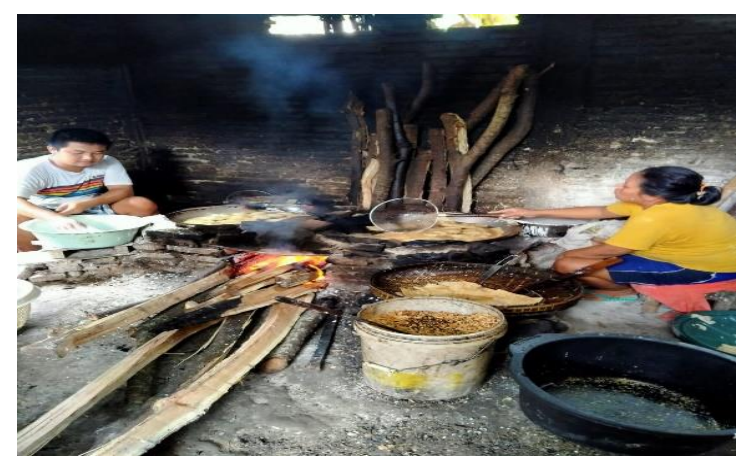

Gambar 2. Proses Penggorengan Kripik

c. Proses Pengepakan

Pengepakan produk ini dibedakan menjadi beberapa jenis, yaitu: kecil, sedang, besar atau menyesuaikan pesanan. Harga pack kecil Rp 1.000/pack, harga pack sedang Rp 3.500/pack, dan harga pack besar Rp 10.000/pack (pengepakan ketiga tipe ini dilakukan setiap hari), sedangkan apabila ada pesanan menyesuaikan permintaan pembeli.

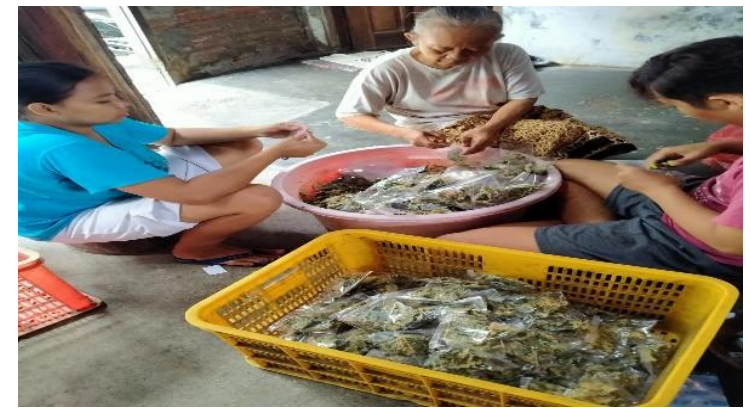

\section{Gambar 3. Pengepakan menggunakan} steples

d. Kegiatan Pemasaran

Pemasaran kripik tempe dan kripik bayam yang dilakukan oleh Home Industry Sumber Agung masih sederhana, hanya menggunakan cara penjualan langsung (direct selling), yang dilakukan oleh pemilik dan dibantu oleh keluarganya.

Berdasarkan latar belakang dan profil mitra tersebut, tim pengabdian menemukan permasalahan yang dapat kelompokkan menjadi 2 (dua) yaitu:

a. Masalah internal, antara lain:

1) Pengirisan tempe yang dilakukan secara manual, menyebabkan tingkat ketebalan irisan tempe tidak merata/homogen

2) Proses penggorengan yang menggunakan bahan bakar dengan kayu bakar, menyebabkan aspek higienitas/kebersihan kurang diperhatikan

3) Pengepakan tempe yang dilakukan kurang memahami pentingnya branding dan packing, karena hanya dilakukan secara sederhana dan menggunakan steples dalam pengepakannya.

4) Pemasaran dilakukan secara tradisional, hanya mendasarkan dari mulut ke mulut (mouth to mouth) dan penjualan dilakukan secara langsung (direct selling).

b. Masalah eksternal

Terjadinya pandemi covid 19 menyebabkan volume/omset penjualan kripik tempe dan kripik bayam yang dihasilkan oleh Home Industry Sumber Agung mengalami penurunan. 
Rencana pemecahan masalah, tim pengabdian melakukan pendampingan pada Home Industry Sumber Agung, secara tehnis dalam bentuk pelatihan dan penyuluhan agar permasalahan yang dihadapi dapat teratasi. Dalam pelaksanaannya, tim menentukan jadwal pelatihan dan penyuluhan kepada mitra, berdasarkan kesepakatan antara tim dengan mitra (Sumber Agung).

Tujuan dari kegiatan pengabdian ini adalah untuk membantu memberikan solusi terhadap permasalahan yang dihadapi, khususnya penurunan omset penjualan di masa pandemi covid 19 dengan harapan Home Industry Sumber Agung tetap eksis menjalankan usahanya dan mampu bertahan.

\section{METODE PELAKSANAAN}

Metode pelaksanaan yang digunakan yaitu pendampingan dan penyuluhan terhadap pemilik dan karyawan, dengan tetap menerapkan protokol kesehatan karena masih terjadinya pandemi covid 19. Jadwal pendampingan dan pelatihan yang akan dilaksanakan, berdasarkan kesepakatan antara tim pengabdian dengan mitra, rencana pelaksanaan dijadwalkan sebagai berikut :

a. Hari Selasa, 2 Maret 2021 tim mengadakan pelatihan tentang pentingnya memahami strategi pemasaran produk (product marketing strategic), meskipun hanya usaha mikro, dengan memanfaatkan perkembangan tehnologi yang terus berubah.

b. Hari Jum'at, 26 Maret 2021 tim mengadakan penyuluhan tentang pentingnya menciptakan efisiensi dan efektivitas menghasilkan produk dengan menggunakan mesin, sekaligus tentang pentingnya menjaga higienitas/kebersihan produknya.

c. Hari Jum'at, 9 April 2021 tim mengadakan penyuluhan tentang pentingnya menciptakan kesan terhadap produknya (brand image), supaya pembeli produk dapat menjadi pelanggan.

\section{HASIL DAN PEMBAHASAN}

Hasil dari pelaksanaan pendampingan dibagi dalam beberapa tahap, yaitu: a. Pada hari Selasa, 2 Maret 2021, tim pengabdian melakukan pengabdian dengan metode pelatihan ke pemilik usaha Sumber Agung (Ibu Supriyanti), tentang pentingnya menerapkan strategi pemasaran produk kripik tempe dan kripik bayam, dengan memanfaatkan perkembangan tehnologi, misalnya melalui Whatsapp, Facebook dan Instagram. Hasil dari kegiatan pelatihan ini yaitu dalam upaya meningkatkan volume penjualan kripik tempe dan kripik bayam, Sumber Agung menggunakan sosial media Facebook dengan nama Keripik Sumber Agung dan Instagram dengan nama Sumberagungsolo.

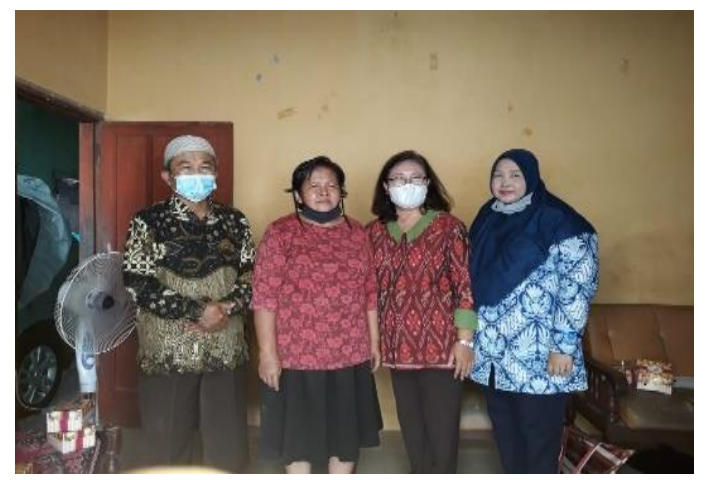

Gambar 4. Pelatihan Penggunaan

Sosial Media

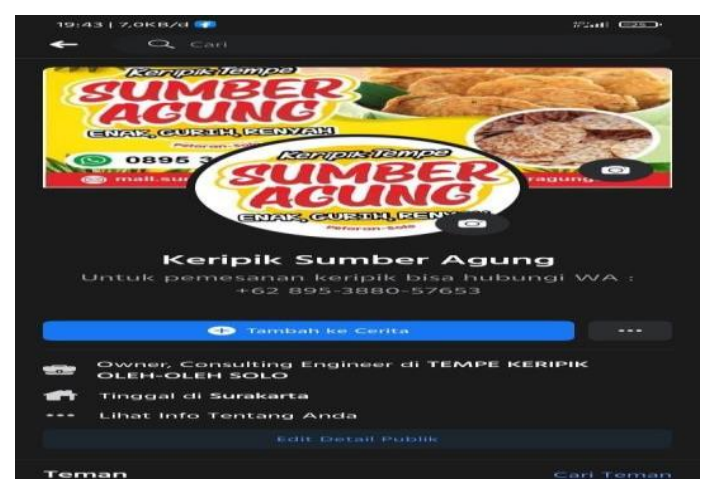

Gambar 5. Akun Media Sosial Facebook

b. Pada hari Jum'at 26 Maret 2021, tim pengabdian berkunjung lagi ke home industry Sumber Agung, dengan memberikan penyuluhan kepada pemilik Sumber Agung, tentang pentingnya menciptakan efisiensi dan efektiktivitas 
menghasilkan kripik tempe menggunakan mesin.

Tabel 1. Keunggulan Produksi Tempe dengan Menggunakan Mesin

\begin{tabular}{cll}
\hline No & Komponen & Keunggulan \\
\hline 1 & Beban pekerjaan & Lebih ringan \\
2 & Kapasitas & Lebih besar \\
3 & produksi & Sama/homogen \\
4 & Ukuran & Lebih \\
& ketebalan irisan & cepat/efisien \\
& Waktu proses & \\
& produksi & \\
\hline
\end{tabular}

Hasil dari kegiatan ini, diharapkan agar pemilik Sumber Agung dapat lebih banyak menggunakan mesin pengiris tempe, dibanding dilakukan secara manual, karena hasil akhir akan lebih efisien dan efektif.

c. Pada hari Jum'at 9 April 2021, tim pengabdian berkunjung lagi ke home industry Sumber Agung, dengan memberikan penyuluhan tentang pentingnya brand image product (branding dan packing). Hasil dari kegiatan pengabdian ini, yaitu tim pengabdian mencoba memberikan label kripik tempe Sumber Agung dengan tampilan berwarna (color), agar lebih menarik. Perubahan label kemasan yang lama menjadi label kemasan yang baru, tampak pada Gambar 6 dan 7 berikut ini:

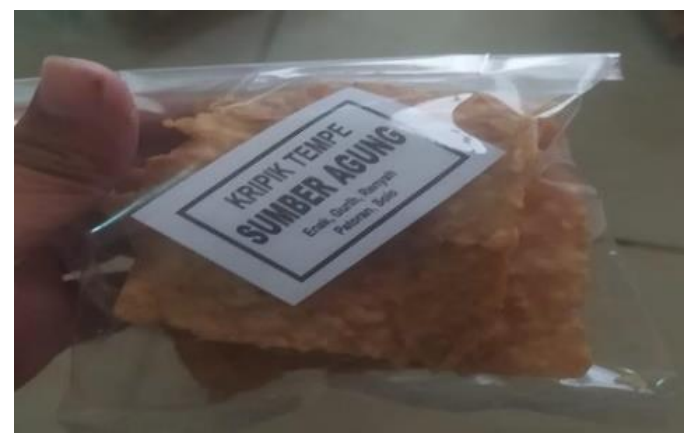

Gambar 6. Label Kemasan Lama

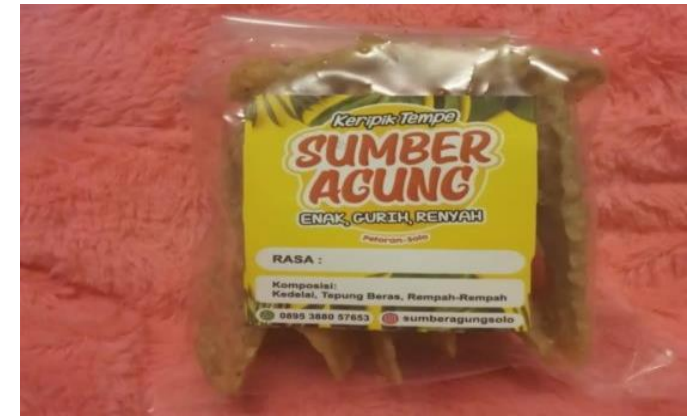

\section{Gambar 7. Label Kemasan Baru}

Keunggulan yang dimiliki Home Industry Sumber Agung (mitra), memiliki keyakinan dan kepercayaan yang tinggi bahwa usaha yang telah digeluti selama kurang lebih 30 tahun, akan tetap eksis meskipun dalam kondisi pandemi.

Sedangkan kelemahan yang dimiliki mitra yaitu manajemen usaha usahanya benar-benar sangat sederhana, baik dari segi keuangan, produksi, maupun pemasarannya.

Kendala yang dihadapi mitra dalam kondisi pandemi Covid 19 ini, yaitu harga bahan baku kedelai yang melonjak, sehingga mempengaruhi cash flow usaha, tetapi peluang pasar kripik tempe maupun kripik bayam terbuka luas.

\section{SIMPULAN}

Tingkat ketercapaian antara target dan metode pelaksanaan pengabdian sebesar $95 \%$, karena kesepakatan yang telah disepakati di awal kegiatan dengan pelaksanaan bisa berjalan seperti yang diharapkan.

Hasil dari kegiatan pengabdian yang telah dilakukan, antara lain:

a. Home Industry Sumber Agung telah menggunakan media sosial Facebook dan Instagram dalam upaya untuk meningkatkan volume penjualan, dengan harapan pangsa pasar yang dikuasai semakin luas

b. Home Industry Sumber Agung dalam upaya meningkatkan volume penjualan dan efisiensi produksi, merencanakan dengan menggunakan mesin pengiris tempe.

c. Home Industry Sumber Agung membuat dan memperbarui label kemasan produk. Label kemasan produk kripik yang lama tidak berwarna diganti dengan label 
kemasan yang berwarna, dengan harapan dapat merubah brand image produk kripik tempe Sumber Agung, sehingga dapat meningkatkan volume penjualan.

Program pengabdian ini telah terlaksana dengan baik, dan tim merencanakan akan menindaklanjuti pengabdian berikutnya, dengan mencoba membuat proposal hibah pengabdian yang diajukan ke Dikti, untuk menunjang ketersediaan alat produksi yaitu mesin pengiris tempe.

\section{UCAPAN TERIMA KASIH}

Ucapan terima kasih disampaikan kepada:

a. Unisri Surakarta melalui LPPM yang telah memfasilitasi dan mendanai pelaksanaan pengabdian kepada masyarakat ini.

b. Pemilik Home Industry Sumber Agung (Ibu Supriyanti) yang telah berkenan digunakan sebagai mitra program pengabdian kepada masyarakat.

c. Mas Adi, putra dari Ibu Supriyanti, yang telah banyak membantu memberikan datadata terkait pelaksanaan kegiatan pengabdian ini.

\section{REFERENSI}

[1]Afandi, Yusuf, 2020, Strategi Pemasaran dan Branding pada Home Industry Sumber Agung di Era Digital, Laporan PKM, Universitas Slamet Riyadi, Surakarta.

[2]Armi, A. 2020, "Dampak Covid 19 Terhadap UMKM di Indonesia", Jurnal Brand, Volume 2, hal 27.
[3]Frinces, Heflin, 2004, Kewirausahaan dan Inovasi Bisnis, Darussalam Offset, Yogyakarta.

[4]Khan, N. and Faisal, S. 2020, "Epidemiology of Corona Virus In the Word and Its Effects On the China Economy". SSRN Electronic Journal. https://doi.org/10.2139/ssrn.3548292

[5]Leboeuf, Michael, 2006, Kiat-Kiat Menjadi Entrepreneur Sukses, Alih Bahasa: Suyanto, Prestasi Pustakaraya, Jakarta.

[6]Wiratmo, Masykur, 2007, Pengantar Kewiraswastaan, BPFE UGM, Yogyakarta.

[7]Taufik, T., dan Ayuningtyas, E.A, 2020, "Dampak Pandemi Covid 19 Terhadap Bisnis dan Eksistensi Platform Online", Jurnal Pengembangan Wiraswasta, Vol. 22, No. 01. Hal 21. https://doi.org/10.33370/jpw.v22i01.38 9

[8]Thobymutis, 2010, Kewirausahaan yang Berpotensi, Gramedia Widia Sarana, Indonesia. 